\title{
Holmes and the History of Detective Fiction
}

\section{Merrick Burrow}

In the summer of 1927, shortly after publishing his final Sherlock Holmes story and just three years before his death, Arthur Conan Doyle recorded one of the first ever sound-on-film interviews. In it he recounts how he first came to write the Holmes stories, stressing the significance of his own scientific training as a medical doctor and his dissatisfaction with some of the 'old-fashioned' detective stories that he used to read for pleasure. In these, he suggests, 'the detective always seemed to get at his results either by some sort of a lucky chance or fluke, or else it was quite unexplained how he got there ... That didn't seem to me quite playing the game'. Beyond his sense of annoyance with these stories, Doyle explains, he saw a gap in the literary marketplace and 'began to think of turning scientific methods, as it were, onto the work of detection'. He describes how he drew inspiration from the example of Joseph Bell, one of the lecturers from his medical school, whose powers of observation enabled him not only to diagnose patients' diseases but also 'very often their nationality and occupation and other points'. It was the example of Bell, Doyle suggests, that gave him 'a new idea of the detective'. ${ }^{1}$

It is with a palpable sense of bemusement that Doyle describes how his 'new' detective subsequently developed from this 'comparatively small seed' into a 'monstrous growth' after Holmes began to appear in short story form in The Strand Magazine in $1891 .^{2}$ As Holmes's popularity 'took root' avid fans began to write him letters, applying for positions as domestic servants and even offering unsolicited advice on beekeeping when Holmes 'retired'. These were not the only ways in which the Great Detective outgrew Doyle's original conception. More significant from a literary perspective is the manner in which Holmes has come to be viewed as synonymous with nineteenth-century detective 
fiction in general, a Victorian giant who eclipses his literary forebears and peers alike, and whose influence has shaped the conventions of the detective genre, either by emulation or by dissent, ever since.

Doyle's reflections in the filmed interview suggest that the source of Holmes's success lay in the originality of his application of scientific methods to the "work of detection' - thus allowing readers the chance of solving the mysteries themselves. But Doyle's comments on the 'old-fashioned detective' also highlight the fact that the genre began long before Holmes appeared in print. So, in fact, did the type of fictional detective who employed scientific methods to solve mysteries. The extent of Holmes's dominance in our perceptions of late-Victorian detective fiction might lead one to the conclusion that Doyle was the most successful practitioner of detective fiction, even if he did not invent the genre or the scientific method. But even this is not altogether correct. Why, then, does Holmes loom so large in the history of detective fiction? In the first part of this chapter I will examine some of the late-Victorian detective fiction against which Doyle defined his 'new' detective, before exploring the influence of Edgar Allan Poe and Émile Gaboriau. I will then survey some of Holmes's competitors and consider the reasons why he eventually prevailed in shaping the direction that the genre would take. The final part of the chapter traces the course of Holmes's influence in the development of the whodunit and hardboiled American private eye thrillers as well as the wider field of crime writing.

\section{Holmes's Precursors}

The most successful detective story of the nineteenth century, judged by volume of sales at least, was not written by Doyle but by a New Zealand barrister named Fergus Hume, whose first novel The Mystery of a Hansom Cab (1886) sold over 300,000 copies in Britain alone during the first six months of publication. Hume had wanted to pursue a career as a 
playwright in Melbourne, where he moved shortly after being admitted to the bar in 1885 . Finding it difficult to be taken seriously by theatre directors, he set about writing a novel that would raise his literary profile. Hume was aiming for maximum attention and, with that in mind, he consulted with a bookseller as to which were the most popular books.

He replied that the detective stories of Gaboriau had a large sale; and as, at this time, I had never even heard of this author, I bought all his works - eleven or thereabouts and read them carefully. The style of these stories attracted me, and I determined to write a book of the same class; containing a mystery, a murder, and a description of low life in Melbourne. ${ }^{3}$

Hume, up until that point a comparative stranger to the detective genre, rightly assumed that his imitation of Gaboriau's established formula would do well in the popular fiction market. Even so, he could not have anticipated the scale of his book's eventual success. The publishers he initially approached rejected his novel and Hume resorted to printing 5,000 copies at his own expense. Sales in Australia were brisk but still Hume did not appreciate the book’s commercial potential, selling the rights to his novel for just $£ 50$ in advance of the first London printing in November 1887. By the following May, The Mystery of a Hansom Cab had sold 200,000 copies and its sales continued at the rate of around 3000 copies per day. ${ }^{4}$

Hume's detective novel was a popular sensation. Critics, however, were equally enthusiastic in their condemnation of it, describing The Mystery of a Hansom Cab as 'valueless' from a literary perspective and 'beneath contempt' in its style - none of which had any effect in dampening sales. ${ }^{5}$ Doyle's first foray into detective fiction, A Study in Scarlet, was published the month following The Mystery of a Hansom Cab. In contrast to Hume's bestseller, A Study in Scarlet had meagre sales and received scant critical attention. Stung by their contrasting fortunes, Doyle was scathing in his assessment of Hume's novel: 
'What a swindle "The Mystery of a Hanson Cab" is. One of the weakest tales that I have read, and simply sold by puffing ${ }^{6}{ }^{6}$ Doyle's novel could hardly have been more different from The Mystery of a Hansom Cab. Unlike Holmes, Hume's detectives are either inept or corrupt, while the eventual solution of the crime arises from a chance discovery rather than scientific detection. It was perhaps with Hume's outrageously successful novel in mind that Doyle retrospectively bristled at the thought of the detective who was not 'playing the game'.

The Mystery of a Hansom Cab had demonstrated the spectacular commercial possibilities of crime fiction but Hume's detectives possessed none of Bell's analytical acumen. For this - and for the template for what would come to be known as 'classic' detective fiction - Doyle drew upon three 'tales of ratiocination' written in the 1840s by Edgar Allan Poe, in which enigmatic crimes are solved through the intellectual acuity of C. Auguste Dupin: 'The Murders in the Rue Morgue' (1841), 'The Mystery of Marie Rôget' (1841-2) and 'The Purloined Letter' (1845). Doyle remarked in his autobiographical Memories and Adventures that 'Poe's masterful detective, M. Dupin, had from boyhood been one of my heroes'. ${ }^{7}$ Following Tzvetan Todorov's well-known typology, the Dupin stories consist of two distinct narratives: that of the crime and that of the investigation. In classic detective fiction of this type (including the Holmes stories) the narrative of the investigation is centred on the detective and is typically narrated by a third party, such as Watson. The story of the crime, on the other hand, is usually recounted by the detective as the solution to the mystery. The figure of the detective thus became central in a way that was quite distinct from earlier crime fiction, in which the narrative was primarily focalised around the exploits of a criminal. In the classic detective story the crime is principally significant as the occasion for a demonstration of the detective's acumen. This is foregrounded in Poe's stories by the prefacing of the crime narrative with a miniature essay on some specific aspect of analytical reasoning, such as a discussion at the outset of 'The 
Murders in the Rue Morgue' of the qualities of analytical observation at work in games of chess, draughts and whist, which are then demonstrated by Dupin in the solution of the crime.

'The Murders in the Rue Morgue' is also a founding example of the 'locked room' subgenre of detective fiction. The story concerns the discovery of the bodies of two women in a locked upper-storey apartment in Paris who have been murdered with extreme brutality. In addition to the mystery of how the murderer got in and out of the apartment the case presents other problems that baffle the official police, including the fact that no valuables had been taken and that witnesses reported hearing an extremely strange voice that no one could identify. Dupin solves the case by virtue of his skills in observation and analysis concluding, for example, that witnesses' disagreement on the characteristics of the voice pointed to the fact that it was not a human voice at all. This inference also accounts for the other peculiar features of the case: the climbing agility required to scale the building, the indifference to valuables and the extreme nature of the violence of the crime. The perpetrator, Dupin concludes, was an escaped Orang-utan.

The influence of 'The Murders in the Rue Morgue' upon the Holmes stories can be seen not only in the foregrounding of the detective's acumen but also in his pairing with a confidential narrator. Doyle even adapted the plot of Poe's story for his second Holmes novel The Sign of Four, in which Bartholomew Sholto is discovered murdered in a locked attic room; the murderer in this case being an Andaman Islander who could "climb like a cat"" (156). In 'The Purloined Letter' Dupin seeks to recover a compromising document that has been stolen from the Queen by a government minister, who is using it to exercise power over her. Dupin, reflecting upon the bold character of the minister, speculates that he would be likely to adopt the principle of hiding the letter in plain sight, using excessive obviousness as a technique of misdirection. Dupin visits the minister upon some pretext and, after deducing that a crumpled letter dangling from the mantelpiece is the one stolen from the Queen, he 
uses a pre-arranged disturbance in the street outside to distract the minister's attention while he retrieves it. The plot of the first Holmes story to appear in The Strand Magazine, 'A Scandal in Bohemia', is a variation on the same plot, in which the Prince of Bohemia seeks Holmes's assistance to recover a compromising photograph, whose hiding place Holmes also discovers with the aid of assistants who create a disturbance outside.

Dupin is invoked in Doyle's 'The Fate of the Evangeline', published two years before his first Holmes story: “"Exclude the impossible," [Dupin] remarks in one of Poe's immortal stories, "and what is left, however improbable, must be the truth". ${ }^{8}$ Dupin, in fact, never utters this dictum in quite such a pithy formulation. The phrase is Doyle's own, and it is one that Holmes adopts as his own in The Sign of Four and elsewhere. Holmes's debt to Dupin is touched upon directly during the course of a disquisition upon the 'science of deduction' in the second chapter of A Study in Scarlet, in which Watson comments upon the similarity between Poe's detective and Holmes. Surprisingly, perhaps, Holmes rejects the comparison: “"Now, in my opinion, Dupin was a very inferior fellow. That trick of his of breaking in on his friends' thoughts with an apropos remark after a quarter of an hour's silence is really very showy and superficial. He had some analytical genius, no doubt; but he was by no means such a phenomenon as Poe appeared to imagine"” (24). Holmes's churlishness here is perhaps best understood as the product of Doyle's own literary insecurity at a time when the manuscripts he sent out to publishers 'used to come circling back with the precision of a homing pigeon'. ${ }^{9}$ The problem, as Doyle acknowledged, was that these early works of fiction were 'too reminiscent of the work of others' ${ }^{10}$ However, with A Study in Scarlet Doyle felt that he was onto something and so 'when my little Holmes book began also to do the circular tour I was hurt, for I knew that it deserved a better fate'. ${ }^{11}$ Holmes did not find his niche until he began to appear in short stories in The Strand in 1891, which quickly established reader loyalty both to the character and the publication. Holmes's market potential had finally been 
recognised as a figure in a linked series of short stories. Upon receiving the manuscript for 'A Scandal in Bohemia' Herbert Greenhough Smith, the magazine's editor, reportedly ran into the office of its owner, George Newnes, declaring that he had discovered the greatest writer of short stories since Edgar Allan Poe. ${ }^{12}$

This change in Doyle's literary fortunes, and the assurance of an established place of publication for Holmes, allowed for a more generous acknowledgement of Dupin and Poe. In 'The Cardboard Box' Holmes ascribes his former view of Dupin to Watson, remarking that “"some little time ago when I read you the passage in one of Poe's sketches in which a close reasoner follows the unspoken thoughts of his companion, you were inclined to treat the matter as a mere tour-de-force of the author". Holmes adds that he is "“constantly in the habit of doing the same thing"' as Dupin (888), a point which he practically demonstrates by breaking in on Watson's own internal thought processes. However, when it came to publishing the stories from The Strand in a single volume, Doyle left out 'The Cardboard Box' because he felt its subject matter was unduly gruesome (in the story a woman is sent a cardboard box containing two severed human ears). It is therefore a mark of the importance that Doyle placed upon paying tribute to Dupin that he transplanted the thought-reading episode into the opening scene of 'The Resident Patient' when it was re-published in The Memoirs of Sherlock Holmes (1894).

In his preface to a 1902 edition of The Adventures of Sherlock Holmes Doyle went even further, giving Poe comprehensive credit for the entirety of the classic detective fiction genre:

Edgar Allan Poe ... was the father of the detective tale, and covered its limits so completely that I fail to see how his followers can find any fresh ground which they can call their own. For the secret of the thinness and also of the intensity of the detective 
story is, that the writer is left with only one quality, that of intellectual acuteness, with which to endow his hero. Everything else is outside the picture and weakens the effect. The problem and its solution must form the theme, and the character-drawing be limited and subordinate. On this narrow path the writer must walk, and he sees the footmarks of Poe always in front of him. He is happy if he ever finds the means of breaking away and striking out on some little side-track of his own. ${ }^{13}$

Poe may have been the single most important influence upon Doyle in the early Holmes stories, but he was certainly not the only one. Doyle incorporated motifs borrowed from Wilkie Collins's The Moonstone (1868) into The Sign of Four, including a conspiracy originating from India, jewel theft, drug addiction, a dishonourable army officer and another estimable detective in the form of Sergeant Cuff. In the same passage from A Study in Scarlet in which Holmes ungraciously disavows comparison with Dupin he also rejects Lecoq, the detective made famous in Gaboriau's L'Affaire Lerouge (1865) and Monsieur Lecoq (1868), which enjoyed tremendous sales until Holmes eclipsed their popularity in the 1890s. Asked by Watson what he thinks of Gaboriau's detective, Lecoq, Holmes sardonically describes his French precursor as "“a miserable bungler"” (25). But here, too, Doyle betrays an anxiety of influence rather than genuine disdain. Holmes's methods of close observation and inference resemble to a remarkable degree those of Gaboriau's detective. Lecoq was, in turn, modelled on a combination of Dupin (Gaboriau being another of Poe's literary admirers) and the reallife detective and sometime criminal Eugène François Vidocq, the first director of the Sûreté Nationale whose sensational Mémoires de Vidocq (1828) had themselves served as inspiration for literary policemen and criminals in Honoré de Balzac's Le Père Goriot (18345), Eugène Sue's Les Mystères de Paris (1842-3), Alexandre Dumas's Les Mohicans de Paris (1854-5) and Victor Hugo's Les Miserables (1862). Vidocq is also mentioned in 'The 
Murders in the Rue Morgue' by Dupin who, like Holmes, gives his progenitors short shrift, describing Vidocq as “"a good guesser, and a persevering man. But, without educated thought, he erred continually by the very intensity of his investigations. He impaired his vision by holding the object too close". ${ }^{14}$

This pattern of disavowal delineates a chain of influence connecting Holmes to Vidocq via Poe and Gaboriau. Poe's short stories provided direct inspiration for some of Doyle's plots. Likewise, the two-part structure of both A Study in Scarlet and The Valley of Fear (1914-15) is indebted to Gaboriau, whose novels are similarly divided into distinct parts dealing firstly with the narrative of the detective's enquiry into a crime and followed by a narrative that unfolds its back-story. In Gaboriau's novels, however, the solution to the crime emerges from details that are not available to the detective or the reader within the narrative of the investigation. In Doyle's terms they are 'old-fashioned' detective stories that are not 'playing the game'. Gaboriau's stories also differ from the tales of Dupin and Holmes insofar as the boundary between Lecoq and his criminal quarry is relatively porous - as indeed it had been for Vidocq who was recruited from the ranks of the criminal underworld. Holmes's identification with the criminal mind, on the other hand, is only ever a matter of intellectual interest; a point that is reinforced from time to time by Watson's reassuring observation that is was fortunate for society that Holmes had adopted the profession of the consulting detective rather than that of the master criminal - an alternative possibility that is projected instead into the figure of his nemesis, Professor Moriarty.

\section{Holmes's Competitors}

Doyle left the field wide open for imitators when, in December 1893, Holmes plunged with Moriarty into the chasm of the Reichenbach Falls. There was no shortage of candidates to replace him or to emulate his tremendous commercial success. Of these, the most immediate 
substitute for Holmes came in the form of Arthur Morrison's private investigator, Martin Hewitt, whose tales, starting with 'The Lenton Croft Robberies' (March 1894), graced the pages of The Strand Magazine in Holmes's wake. With Hewitt, Morrison followed fairly closely the formula that Doyle had adopted from Poe and developed around Holmes, producing a series of stories linked by the central character of the detective, an associate who narrates and a plot focused upon an investigation in which Hewitt uses observation and logic to solve enigmatic crimes. Morrison did not simply make a clone of Holmes, however; he gave Hewitt a more genial and down-to-earth persona that contrasted with Holmes's artistic hauteur. But Morrison was nevertheless plugging an obvious gap in the market that Doyle had recently vacated, as were a number of his contemporaries. These included L.T. Meade, whose Stories from the Diary of a Doctor began appearing in The Strand in July 1893, developing the subgenre of the medical mystery story that Doyle himself had pioneered in some of his early stories that were later collected under the title Round the Red Lamp (1894). Grant Allen, another of Doyle's contemporaries who also stepped into the space left by Holmes, published the majority of his detective fiction in The Strand during the interregnum between 'The Final Problem' and The Hound of the Baskervilles. Allen had already published occasional detective stories, such as 'The Great Ruby Robbery' (1892) but his major contribution to the genre came in three sets of interconnected stories: An African Millionaire (June 1896 and May 1897), Miss Cayley's Adventures (March 1898 to February 1899), and Hilda Wade (March 1899 to February 1900). Allen became terminally ill during the publication run of Hilda Wade and, in an act of professional friendship, Doyle undertook to complete the final two stories to relieve his fellow author's mind. ${ }^{15}$

Doyle's readiness to pick up the baton suggests that both he and Allen felt there was a reasonable amount of common ground between them, at least in their manner of writing detective stories. Allen's radical views in respect of gender, marriage and sexuality were a 
world away from Doyle's own conservative attitudes. But both men accommodated themselves to the remit of The Strand's offering of 'cheap, healthful literature'. ${ }^{16}$ Hilda Wade is nonetheless a notable departure from the Holmes stories in its treatment of detection as a matter of interpretation of character as much as the analysis of material clues. Hilda Wade, the sleuth, is a nurse endowed with a particularly heightened capacity for 'female intuition'. She is aided in her investigations by Dr Hubert Cumberledge, who is both her narrating Watson and eventual lover - a radical twist on the sidekick motif and a departure from the homosocial ethos of the Holmes stories.

Allen and Meade were not alone in the 1890s in their search for an alternative niche in the literary marketplace to that of the Holmesian detective story. Morrison, whose Martin Hewitt tales were widely viewed as inferior imitations of Holmes, attempted a bold departure with a series of detective stories gathered under the title of The Dorrington Deed-Box (1897). James Rigby, a young heir to a fortune narrates the first story of the series, in which he tells of how he met a detective named Dorrington, to whom he confided the information that Italian Camorra - a mafia-like organisation - had assassinated his father some twenty years previously. Soon afterwards Rigby notices that he is being followed and begins to fear the same fate when he finds the sign of the Camorra fixed to his hotel room door. He seeks advice and assistance from Dorrington, who suggests that they exchange identities in order to protect Rigby’s safety. Rigby gives Dorrington documents that establish his identity, and which thereby provide legal access to his inheritance, soon after which he realises that he has been the victim of an elaborate and murderous deception. Rigby awakes from a drug-induced sleep to find that Dorrington has stolen his identity and left him to drown in an iron tank that is filling with water. After escaping from the tank Rigby goes in search of Dorrington, finding only a hastily abandoned office and a box of case files, which provides the framework for the remainder of the series of stories. Morrison's innovation combined the 
identities of criminal and detective, breaking with the Holmesian formula he had followed in the Martin Hewitt stories to produce something much more original. The Dorrington DeedBox was, however, a commercial flop and for the next thirty years or so the mainstream of the detective genre continued to develop along the lines that Doyle had established with Holmes.

It is a testament to the reach and depth of Holmes's influence that the clear separation of detective from criminal, which Morrison attempted to break with in The Dorrington DeedBox, became an unquestionable norm in the Golden Age of detective fiction, as did the idea of deploying clues. In the earliest stories Doyle foregrounds Holmes's remarkable aptitude for reading clues as a sign of his superhuman capacities. But in building the framework for Holmes's accounts of his processes of deduction, Doyle stumbled upon an approach that enabled readers to join in the game, turning the detective method into a technique of interpretation that they might themselves imitate. If this was indeed the key to Holmes's success and longstanding influence, however, it is remarkable how few of the stories make clues genuinely accessible to the reader. It was perhaps only with the benefit of hindsight, at a time when the whodunit was at the height of its popularity, that the importance of 'playing the game' with the reader suggested itself to Doyle as having been the key to Holmes's success. In the early days Doyle was primarily seeking recognition for originality and commercial success. Later, as he tired of writing the Holmes stories, he struggled to breathe life into a format he felt he had already exhausted. Thus it fell to the next generation to formalise the principles of 'fair play' to which writers were expected to conform in the Golden Age of the whodunit.

\section{Holmes's Legacy}

The rules for the writing of detective fiction became so firmly established in the Golden Age that Ronald A. Knox eventually formulated them (with playful irony, it should be noted) into 
the 'Ten Commandments' that he included in his introduction to The Best Detective Stories of 1928-29. In explaining the role of these 'commandments' Knox explained that 'the detective story is a game between two players, the author of the one part and the reader of the other part'. ${ }^{17}$ What had begun as an incidental (and decidedly variable) feature in the Holmes stories hardened in the inter-war years into a set of expectations for a subgenre of detective fiction that, at the same time, acquired distinctive markers of Englishness and an unmistakable upper-middle-class ethos:

$[\mathrm{W}]$ hen we say that the detective story has rules, we do not mean rules in the sense in which poetry has rules, but rules in the sense in which cricket has rules - a far more impressive consideration to the ordinary Englishman. The man who writes a detective story which is 'unfair' is not simply pronounced guilty of an error in taste. He has played foul, and the referee orders him off the field. ${ }^{18}$

Knox evokes an image of the writer as an English gentleman amateur - even if she happened to be female. Indeed, many of the most significant and popular of the writers of whodunits were women: Agatha Christie, Margery Allingham, Dorothy L. Sayers, Ngaio Marsh and Josephine Tey, to mention only the most well-known. There were plenty of male authors of Golden Age murder mysteries too, including Michael Innes, A.A. Milne, Edmund Crispin and Cyril Hare, and fictional detectives of both sexes, of which the most famous are Hercule Poirot, Miss Jane Marple and Lord Peter Wimsey. In general these stories tend towards insularity and nostalgia. They are typically set in rural English villages and aristocratic country houses from which the outside world of urban squalor, restless lower classes, industrial spoliation and the rise of totalitarianism are largely excluded, and in which murder and detection are the elements of a game played between sporting amateurs. Knox's rules of fair play stipulate that the culprit must be introduced early on in the story and that the reader 
must see the same evidence as the detective. Likewise, the distinction between detective and criminal that Doyle had established had to be maintained, and Knox was firm on the point that it was cheating if the detective turned out to be the murderer.

Knox's 'ten commandments' captured both the conservatism and the self-consciously playful spirit of the Golden Age whodunit. But their reduction of detective fiction to the pure form of a game also set the seal upon its imminent stagnation. The deployment of twists, red herrings and so forth were considered legitimate tactics. But the scope for such variations was subject to the law of diminishing returns. The parallel game of clues played by reader and detective that had begun with Doyle eventually exhausted itself in the novels of Agatha Christie. This, perhaps, was reason enough to look for new modes of detective fiction. But there were other reasons to reject not only the baroque murder plots of the Golden Age detective stories, but also their narrow social milieu and their separation of the intellectual game of investigation from the sordid business of crime as a social reality.

When Raymond Chandler wrote 'The Simple Art of Murder' (1944) he was gunning for all three and praising instead Dashiel Hammett, who 'gave murder back to the kind of people that commit it for reasons, not just to provide a corpse; and with the means at hand, not with hand-wrought duelling pistols, curare, and tropical fish'. ${ }^{19}$ Chandler was the most outspoken and, along with Hammet, the most significant of the writers of 'hardboiled' crime fiction that flourished in America between the 1920s and the 1950s. This development in the detective genre was not only a reaction against the contrived enigmas of the whodunit. It grew out of the quintessentially American late-nineteenth century genre of the Western, in which gunslinging cowboys dispatched frontier justice, but transposed it to the urban context of Prohibition-era racketeering and gangsterism. The principal representatives of hardboiled style were the so-called 'Black Mask boys' - Hammett, Chandler, Caroll John Daly, Horace 
McCoy and Paul Cain - all of whom published in Black Mask and other cheap pulp magazines such as Dime Detective and Black Aces.

Chandler credits Doyle as a key pioneer of the detective genre but, unsurprisingly, given his disdain for the artifices of the whodunit, gives him little credit for his role in developing the intellectual games of classic detective fiction. For Chandler, Holmes figures as 'mostly an attitude and a few dozen lines of unforgettable dialogue'. ${ }^{20}$ This might not sound like much, but attitude and dialogue are amongst the most vital components of hardboiled fiction. Chandler's remarks about Holmes clearly demonstrate that there was more than one trajectory to his influence on subsequent developments in crime fiction. The hardboiled detective had become a vulnerable figure in the narrative. He (and it is invariably 'he' in Hammett's and Chandler's stories) does not arrive on the scene of the crime after the moment of danger has passed. The hardboiled detective is an embattled protagonist who is routinely double-crossed, beaten up, drugged and shot at, and whose main objective is to survive rather than to restore social order. Holmes's intellectual showmanship may have been jettisoned, but his physical courage, mental toughness and dogged pursuit of the truth persists in Chandler's famous description of the attitude of his ideal protagonist.

[D]own these mean streets a man must go who is not himself mean, who is neither tarnished nor afraid. The detective in this kind of story must be such a man. He is the hero, he is everything. He must be a complete man and a common man and yet an unusual man. He must be, to use a rather weathered phrase, a man of honor, by instinct, by inevitability, without thought of it, and certainly without saying it. He must be the best man in his world and a good enough man for any world. ${ }^{21}$

Chandler's romantic vision restored a quality of moral integrity to the detective story that Hammett had largely dispensed with in his tales of gangsters and corrupt lawyers such as The 
Maltese Falcon (1930) and The Thin Man (1934). Hammett's detective protagonists were flawed, even corrupt; as much gangsters as detectives, and with a matching capacity for brutality. But in novels such as The Big Sleep (1939), Farewell, My Lovely (1940) and The Long Goodbye (1954) Chandler's most famous detective figure, Philip Marlowe - though similarly exposed to danger - is ironic, intellectual and romantic; as much inclined to respond to an antagonist with sarcasm as with violence. Marlowe is often viewed as a twentiethcentury American revision of the medieval knight errant. But he is also channelling a romantic conception of masculine integrity whose place in detective fiction derives from Holmes. Likewise, Chandler's evocation of the 'mean streets' down which his detective must travel also has Victorian echoes, harking back - consciously or otherwise - to the gritty slum fiction of Arthur Morrison's Tales of Mean Streets (1894). With the exposure of the detective to jeopardy, hardboiled fiction merged the two narratives of the classic detective story into one, immersing the detective directly into the story of the crime itself and transforming it into a thriller in which the chief source of interest is no longer simply the question of who committed a crime in the past but whether the detective will manage to survive the investigation at all - a narrative device that Doyle pioneered in 'The Final Problem'.

In addition to classic and hardboiled detective fiction (both of which have remained popular), Holmes's post-war influence can be seen in police procedural narratives such as the Inspector Gideon series by J.J. Marric, beginning with Gideon's Day (1955-90) and, in America, Ed McBain's $87^{\text {th }}$ Precinct series (1956-2005). These stories shift the focus away from a single detective to represent the workings of investigative teams across multiple crimes. But in their focus upon narratives of investigation and interpretation of material evidence they retain many aspects of the Holmesian model. Continental European writers also built upon the tradition of classic detective fiction, with Georges Simenon's Maigret series of novels (1930-72) retaining a strong focus upon the central detective. Maj Sjöwall 
and Per Wahlöö likewise followed in Doyle's (and Poe's) footsteps with their series of Martin Beck novels between 1965 and 1975, as did Josef Škvorecký with the Prague-based detective Lieutenant Boruvka in a series of stories published between 1966 and 1981.

Looking beyond Western traditions, Holmes's influence made a significant impact in both China and Japan. The first translations of Holmes stories appeared in China as early as 1896 and they continued to be the most commonly translated Western texts up to the end of the late Qing dynasty in 1911, when the traditional feudal social order gave way to a wider influx of Western influences. As Chinese ways of life changed during the early twentieth century, Holmes acquired a new kind of significance. The emphasis upon scientific reasoning in Doyle's stories was seen as a welcome harbinger of modernity and the Holmesian type of detective story quickly began to displace traditional Chinese Gong-an tales, in which revered feudal officials solved crimes. In Japan, too, a tradition of crime and detective fiction developed during the twentieth century under the influence of Western classic detective fiction, whose most notable exponent was Edogawa Rampo (a witty Japanese rendering of the name Edgar Allan Poe that served as the pen name of Tarō Hirai), whose debut work of detective fiction 'Ni-sen dōka' ('The Two-Sen Copper Coin') was published in 1923.

Holmes has been significant to the history of detective fiction not only in the extent of his influence upon the crime writers that came afterwards but also in the manner in which his figure has cast a shadow over both his precursors and peers as well. He has become a seemingly permanent fixture in the landscape not only of crime writing, but also of TV and film adaptation, fan fiction and graphic novels. Furthermore, his significance has always been multifaceted, as is illustrated by the different ways in which Holmes influenced both the Golden Age whodunit and the American hardboiled thriller. This variety also shows up in the different possibilities that Doyle's peers explored in their efforts to fill the niche in the market that Holmes vacated in December 1893, many of which (though not all) were very successful 
at the time on their own terms. It is tempting to look for a single continuous narrative that would neatly explain Holmes's overwhelming success and dominance of the field. Doyle himself, when reflecting back on Holmes's 'monstrous growth', put it down to the importance of inserting clues into the Holmes stories as the key to the 'game' that would take centre-stage with the emergence of the Golden Age whodunit. But Doyle's pronouncement -

made at the height of the whodunit's popularity - perhaps only serves to obscure the extent to which Holmes's appeal has in fact always been based upon a range of different features including style, attitude, moral vision and cultural distinctiveness. It is this plurality that has, in different ways and for different reasons, continued to attract readers and to inspire new writers to engage with and reinvent Holmes.

\section{NOTES}

${ }^{1}$ Fox Film Corporation, Arthur Conan Doyle Fox Film Corporation, 1927, http://archive.org/details/SirArthurConanDoyleSpeaks_272.

${ }^{2}$ Ibid.

${ }^{3}$ Fergus Hume, 'Preface', The Mystery of a Hanson Cab (Sydney: Sydney University Press, 2010), xi-xiv (xii).

${ }^{4}$ Christopher Pittard, Purity and Contamination in Late Victorian Detective Fiction (Farnham: Ashgate, 2011), 29.

${ }^{5}$ Quoted in Clare Clarke, Late Victorian Crime Fiction in the Shadows of Sherlock (London: Palgrave Macmillan, 2014), 46; Pittard, Purity and Contamination, 30.

${ }^{6}$ Jon Lellenberg et al. (eds), Arthur Conan Doyle: A Life in Letters (New York: The Penguin Press, 2007), 250. 
${ }^{7}$ Arthur Conan Doyle, Memories and Adventures : An Autobiography (London: Hodder \& Stoughton, 1924), 51.

${ }^{8}$ Arthur Conan Doyle et al., Uncollected Stories : The Unknown Conan Doyle (London:

Secker \& Warburg, 1982), 193.

${ }^{9}$ Doyle, Memories and Adventures, 69.

${ }^{10}$ Ibid.

${ }^{11}$ Ibid.

${ }^{12}$ Mike Ashley, Adventures in the Strand: Arthur Conan Doyle and the Strand Magazine (London: British Library Board, 2016), 46.

${ }^{13}$ Arthur Conan Doyle, 'Preface', The Adventures of Sherlock Holmes (New York: D. Appleton \& Co, 1902), v-viii (vi).

${ }^{14}$ Edgar Allan Poe, Tales of Mystery And Imagination (London: Everyman, 1993), 425.

${ }^{15}$ Doyle, Memories and Adventures, 254-5.

${ }^{16}$ George Newnes, 'Introduction', The Strand Magazine 1 (January 1891), 3.

${ }^{17}$ Ronald Knox, 'Introduction', in The Best Detective Stories of the Year: 1928, ed. Ronald Knox and Henry Harrington (London: Faber \& Gwyer, 1929), vii-xxiii (x).

${ }^{18}$ Ibid., $\mathrm{x}-\mathrm{xi}$.

${ }^{19}$ Raymond Chandler, 'The Simple Art of Murder', in Pearls Are a Nuisance (London: Penguin Books, 1964), 181-199 (195).

${ }^{20}$ Ibid., 185.

${ }^{21}$ Ibid., 198. 